\title{
Docosahexaenoic acid reduces the incidence of early afterdepolarizations caused by oxidative stress in rabbit ventricular myocytes
}

\section{Zhenghang Zhao ${ }^{1,2}$ *, Hairuo Wen ${ }^{2}$, Nadezhda Fefelova ${ }^{2}$, Charelle Allen ${ }^{2}$, Nancy Guillaume ${ }^{2}$, Dandan Xiao $^{1}$, Chen Huang ${ }^{1}$, Weijin Zang ${ }^{1}$, Judith K. Gwathmey ${ }^{3,4}$ and Lai-Hua Xie ${ }^{2 *}$}

1 Department of Pharmacology, School of Medicine, Xi'an Jiaotong University, Xi'an, China

${ }^{2}$ Department of Cell Biology and Molecular Medicine, UMDNJ-New Jersey Medical School, Newark, NJ, USA

${ }^{3}$ Gwathmey Inc., Cambridge, MA, USA

${ }^{4}$ School of Optometry, Massachusetts College of Pharmacy and Health Sciences, Worcester, MA, USA

\section{Edited by:}

George E. Billman, The Ohio State

University, USA

\section{Reviewed by:}

Gudrun Antoons, Medical University of Graz, Austria

Carmen Valenzuela, Instituto de

Investigaciones Biomédicas

CSIC-UAM, Spain

*Correspondence:

Zhenghang Zhao, Department of

Pharmacology, School of Medicine

Xi'an Jiaotong University, Xi'an

710061, China.

e-mail: zzh@mail.xjtu.edu.cn,

Lai-Hua Xie, Department of Cell Biology and Molecular Medicine, UMDNJ-New Jersey Medical School, Newark NJ 07101, USA.

e-mail:xiela@umdnj.edu
Accumulating evidence has suggested that $\omega 3$-polyunsaturated fatty acids ( $\omega 3$-PUFAs) may have beneficial effects in the prevention/treatment of cardiovascular diseases, while controversies still remain regarding their anti-arrhythmic potential. It is not clear yet whether $\omega$-3-PUFAs can suppress early afterdepolarizations (EADs) induced by oxidative stress. In the present study, we recorded action potentials using the patch-clamp technique in ventricular myocytes isolated from rabbit hearts. The treatment of myocytes with $\mathrm{H}_{2} \mathrm{O}_{2}$ $(200 \mu \mathrm{M})$ prolonged AP durations and induced EADs, which were significantly suppressed by docosahexaenoic acid (DHA, 10 or $25 \mu \mathrm{M} ; n=8$ ). To reveal the ionic mechanisms, we examined the effects of DHA on L-type calcium currents $\left(/_{\mathrm{Ca} . \mathrm{L}}\right)$, late sodium $\left(/_{\mathrm{Na}}\right)$, and transient outward potassium currents $\left(/_{\text {to }}\right)$ in ventricular myocytes pretreated with $\mathrm{H}_{2} \mathrm{O}_{2} . \mathrm{H}_{2} \mathrm{O}_{2}(200 \mu \mathrm{M})$ increased / Ca.L by $46.4 \%$ from control $(-8.4 \pm 1.4 \mathrm{pA} / \mathrm{pF})$ to a peak level $(-12.3 \pm 1.8 \mathrm{pA} / \mathrm{pF}, n=6, p<0.01)$ after 6 min of $\mathrm{H}_{2} \mathrm{O}_{2}$ perfusion. $\mathrm{H}_{2} \mathrm{O}_{2}$-enhanced ICa.L was significantly reduced by DHA $(25 \mu \mathrm{M} ;-7.1 \pm 0.9 \mathrm{pA} / \mathrm{pF}, n=6, p<0.01)$. Similarly, $\mathrm{H}_{2} \mathrm{O}_{2}$-increased the late $/ \mathrm{Na}(-3.2 \pm 0.3 \mathrm{pC})$ from control level $(-0.7 \pm 0.1 \mathrm{pC})$. DHA $(25 \mu \mathrm{M})$ completely reversed the $\mathrm{H}_{2} \mathrm{O}_{2}$-induced increase in late $/_{\mathrm{Na}}$ (to $-0.8 \pm 0.2 \mathrm{pC}$, $n=5) . \mathrm{H}_{2} \mathrm{O}_{2}$ also increased the peak amplitude of and the steady state $I_{\text {to }}$ from $8.9 \pm 1.0$ and $2.16 \pm 0.25 \mathrm{pA} / \mathrm{pF}$ to $12.8 \pm 1.21$ and $3.13 \pm 0.47 \mathrm{pA} / \mathrm{pF}$ respectively $(n=6, p<0.01$, however, treatment with DHA $(25 \mu \mathrm{M})$ did not produce significant effects on current amplitudes and dynamics of $I_{\text {to }}$ altered by $\mathrm{H}_{2} \mathrm{O}_{2}$. In addition, DHA $(25 \mu \mathrm{M})$ did not affect the increase of intracellular reactive oxygen species (ROS) levels induced by $\mathrm{H}_{2} \mathrm{O}_{2}$ in rabbit ventricular myocytes. These findings demonstrate that $\mathrm{DHA}$ suppresses exogenous $\mathrm{H}_{2} \mathrm{O}_{2}$ induced EADs mainly by modulating membrane ion channel functions, while its direct effect on ROS may play a less prominent role.

Keywords: docosahexaenoic acid, $\mathrm{H}_{2} \mathrm{O}_{2}$, early afterdepolarizations, reactive oxygen species, L-type calcium channel, sodium channel

\section{INTRODUCTION}

Extensive studies on the potential effects of fish oil omega-3 poly unsaturated fatty acids ( $\omega-3$ PUFA) on cardiac rhythm have provided controversial results (von Schacky, 2008). While some interventional studies reported either no effect or even promotion of arrhythmias in some subgroups of patients with heart disease (Raitt et al., 2005; Coronel et al., 2007; Den Ruijter et al., 2007; Cheng and Santoni, 2008), other studies have reported beneficial effects of $\omega$-3-PUFAs on cardiac rhythm resulting in a reduction in the incidence of sudden cardiac death or mortality (London et al., 2007; Cheng and Santoni, 2008; Nodari et al., 2009). It seems that fish oil fatty acids may exert either pro- or anti-arrhythmic effects, probably depending on different underlying mechanisms for the arrhythmias. Recent studies have also shown $\omega$-3-PUFAs suppress afterdepolarizations and triggered activities induced by $\mathrm{K}$ channel blockers or by $\beta$-adrenergic stimulation in failing hearts
(Den Ruijter et al., 2006, 2008; Berecki et al., 2007; Smith et al., 2009). However, it is unclear whether $\omega$-3-PUFAs have protective effects on arrhythmias induced by oxidative stress. Reactive oxygen species (ROS) have recently been implicated in the pathogenesis of cardiac arrhythmia during ischemic-reperfusion, aging, and heart failure. Oxidative stress caused by exogenous $\mathrm{H}_{2} \mathrm{O}_{2}$ induces early afterdepolarizations (EADs) and delayed afterdepolarizations (DADs) that may in turn trigger lethal arrhythmias. These afterdepolarizations are a result of a net increase in inward current, which is induced by activation of late sodium current $\left(I_{\mathrm{Na}}\right)$ and the $\mathrm{L}$-type calcium current $\left(I_{\mathrm{CaL}}\right)$ via oxidized $\mathrm{Ca}^{2+} / \mathrm{Calmodulin}$ Dependent Protein Kinase II (CaMKII; Ward and Giles, 1997; Xie et al., 2009; Zhao et al., 2011). Our most recent study suggested that the transient outward potassium current $\left(I_{\mathrm{to}}\right)$ may also facilitate EAD generation by $\mathrm{H}_{2} \mathrm{O}_{2}$ (Zhao et al., 2012b). In the present study, we aim to assess the effects of docosahexaenoic acid (DHA, one of 
$\omega$-3-PUFAs) on exogenous $\mathrm{H}_{2} \mathrm{O}_{2}$-induced EADs, and to further reveal potential underlying ionic mechanisms.

\section{MATERIALS AND METHODS}

This investigation conforms to the Guide for the Care and Use of Laboratory Animals, published by the National Institutes of Health (NIH Publication No. 85-23, Revised 1996). All animal experimental procedures were reviewed and approved by the Institutional Animal Care and Use Committee at the University of Medicine and Dentistry of New Jersey-New Jersey Medical School and by the Ethical Committee of Xi'an Jiaotong University. All experiments were performed at $35-37^{\circ} \mathrm{C}$.

\section{CELL ISOLATION}

Ventricular myocytes were enzymatically isolated from the hearts of New Zealand white rabbits (male, $1.8-2.5 \mathrm{~kg}$ ) as described previously (Xie et al., 2009). Briefly, after rabbits were anesthetized with intravenous pentobarbital hearts were removed and perfused retrogradely at $37^{\circ} \mathrm{C}$ in Langendorff fashion with nominally $\mathrm{Ca}^{2+}$. free Tyrode's solution containing $1.4 \mathrm{mg} / \mathrm{mL}$ collagenase (Type II; Worthington) and $0.1 \mathrm{mg} / \mathrm{ml}$ protease (type XIV, Sigma) for 25$30 \mathrm{~min}$. The hearts were removed from the perfusion apparatus after washing out the enzyme solution, the left ventricles were gently teased apart with forceps in a Petri dish and the myocytes were filtered through a nylon mesh. The $\mathrm{Ca}^{2+}$ concentration was gradually increased to $1.8 \mathrm{mM}$, and the cells were stored at room temperature and used within $8 \mathrm{~h}$.

\section{ELECTROPHYSIOLOGICAL RECORDING}

Myocytes were current-or voltage-clamped using the perforated whole-cell patch-clamp technique $(240 \mu \mathrm{g} / \mathrm{ml}$ amphotericin B; Rae et al., 1991) for recordings of action potential, or $I_{\text {Ca.L }}, I_{\text {to }}$, and late $I_{\mathrm{Na}}$. Voltage or current signals were measured with a MultiClamp 700A patch-clamp amplifier controlled by a personal computer using a Digidata 1322 acquisition board driven by pCLAMP 10 software (Molecular Devices, Sunnyvale, CA, USA).

To record action potentials (APs), patch pipettes (resistance 2$4 \mathrm{M} \Omega$ ) were filled with an internal solution containing (in $\mathrm{mM}$ ): $110 \mathrm{~K}$-aspartate, $30 \mathrm{KCl}, 5 \mathrm{NaCl}, 10$ HEPES, 0.1 EGTA, 5 MgATP, $5 \mathrm{Na}_{2}$-phosphocreatine, 0.05 cAMP, pH was adjusted to 7.2 with $\mathrm{KOH}$. The cells were superfused with Tyrode's solution containing (in mM): $136 \mathrm{NaCl}, 4.0 \mathrm{KCl}, 0.33 \mathrm{Na}_{2} \mathrm{PO}_{4}, 1.8 \mathrm{CaCl}_{2}, 1 \mathrm{MgCl}_{2}, 10$ glucose, and 10 HEPES, $\mathrm{pH}$ was adjusted to 7.4 with $\mathrm{NaOH}$. APs were elicited with $2 \mathrm{~ms}, 2$ to $4 \mathrm{nA}$ square pulses at a pacing cycle length (PCL) of $6 \mathrm{~s}$.

To record the $I_{\mathrm{Ca}, \mathrm{L}}$, patch pipettes $(2-4 \mathrm{M} \Omega$ ) were filled with an internal solution containing (in mM): 110 Cs-Aspartate, $30 \mathrm{CsCl}, 5$ $\mathrm{NaCl}$, 10 HEPES, 0.1 EGTA, $5 \mathrm{MgATP}, 5 \mathrm{Na}_{2}$-phosphocreatine, 0.05 cAMP, pH 7.2 with $\mathrm{CsOH}$, and the cells were perfused with a modified Tyrode's solution, in which $\mathrm{KCl}$ was replaced with $\mathrm{CsCl}$. The myocytes were stimulated at a PCL of $6 \mathrm{~s}$ with a double-pulse protocol. Following a $100-\mathrm{ms}$ prepulse to $-40 \mathrm{mV}$ from the holding potential of $-80 \mathrm{mV}$ (to inactivate $\mathrm{Na}^{+}$current and T-type $\mathrm{Ca}^{2+}$ current), $I_{\text {Ca.L }}$ was elicited by a subsequent test depolarization step to $0 \mathrm{mV}$ for $300 \mathrm{~ms}$.

Late $I_{\mathrm{Na}}$ was measured as described previously (Song et al., 2006). Glass pipettes (1-2 M $\Omega$ ) were filled with an internal solution containing (in mM): 110 Cs-Aspartate, $30 \mathrm{CsCl}, 10 \mathrm{HEPES}$,
0.5 EGTA, $0.2 \mathrm{Na}_{3}$-GTP, $5 \mathrm{Na}_{2}$-phosphocreatine-, $5 \mathrm{MgATP}, \mathrm{pH} 7.2$ was adjusted with $\mathrm{CsOH}$. Myocytes were bathed with a modified Tyrode's solution in which $\mathrm{KCl}$ was replaced with $\mathrm{CsCl}$. Nifedipine $(30 \mu \mathrm{M})$ was added to the bath solution to block calcium channels. Late $I_{\mathrm{Na}}$ was elicited by $300 \mathrm{~ms}$ voltage-clamp pulses from -90 to $-30 \mathrm{mV}$ at a PCL of $6 \mathrm{~s}$ from a holding potential of $-80 \mathrm{mV}$.

To record $I_{\text {to }}$, the pipette and superfusion solutions were the same as those for AP recording. Tetrodotoxin (TTX, $10 \mu \mathrm{M})$ and $\mathrm{CdCl}_{2}(0.5 \mathrm{mM})$ were added into the Tyrode's solution to inhibit $I_{\mathrm{Na}}$ and $I_{\mathrm{Ca}, \mathrm{L}} . I_{\mathrm{to}}$ was evoked by $400 \mathrm{~ms}$ depolarizing pulses to test potentials between -40 and $+50 \mathrm{mV}(0.1 \mathrm{~Hz})$. The holding potential was set at $-80 \mathrm{mV}$ and a $100 \mathrm{~ms}$ prepulse was applied to $-60 \mathrm{mV}$ to inactivate the $I_{\mathrm{Na}} . I_{\text {to }}$ recovery from inactivation was investigated using a conventional two-pulse protocol: an inactivating pulse depolarizing to $+50 \mathrm{mV}$ for $400 \mathrm{~ms}$ (P1) followed by a variable recovery interval and subsequent $+50 \mathrm{mV}$ test pulse (P2). The inactivation of $I_{\text {to }}$ and recovery from inactivation were best fit with a double exponential equation. All electrophysiological data were normalized as current densities by dividing measured current amplitude by whole-cell capacitance.

All chemicals were purchased from Sigma-Aldrich unless indicated. Because DHA is very sensitive to oxidation, DHA (SigmaAldrich) was dissolved in $100 \%$ ethanol under $\mathrm{N}_{2}$ and kept at $-20^{\circ} \mathrm{C}$ in the dark. Immediately before use, the DHA stock solution was diluted in the bath solution to reach the final concentrations needed. The maximum final concentration $(0.1 \%)$ of ethanol had no effect on membrane currents.

\section{MEASUREMENT OF INTRACELLULAR ROS}

The myocytes were incubated with $5 \mu \mathrm{M}$ C-DCDHF-DAAM (Invitrogen) for $30 \mathrm{~min}$. C-DCDHF- DA is oxidized by ROS to dichlorofluorescein (DCF). ROS fluorescence (emission: $\sim 530 \mathrm{~nm}$ ) was measured by a $200 \mathrm{~ms}$-exposure (excitation: $\sim 480 \mathrm{~nm}$ ) every $30 \mathrm{~s}$ using the Andor Ixon charge-coupled device camera. Recordings were started after a stable baseline was achieved.

\section{STATISTICAL ANALYSIS}

Data are presented as mean \pm SEM. Differences were tested for statistical significance by using paired or unpaired Student's $t$ tests, with $p<0.05$ considered significant.

\section{RESULTS \\ DHA SUPPRESSES THE EADS INDUCED BY $\mathrm{H}_{2} \mathrm{O}_{2}$}

Action potentials were recorded from single ventricular myocytes isolated from rabbit hearts using the perforated whole-cell patchclamp technique under current-clamp mode. In order to reliably induce EADs, the cells were paced at a PCL of $6 \mathrm{~s}$ based on our previous studies (Sato et al., 2009; Xie et al., 2009; Zhao et al., 2012a). The average $\mathrm{APD}_{90}$ of rabbit ventricular myocytes is $266 \pm 23 \mathrm{~ms}$ $(n=8)$ at base line. After APD and morphology reached steady state, the cells were perfused with $200 \mu \mathrm{M} \mathrm{H}_{2} \mathrm{O}_{2}$ until EADs consistently appeared. Consecutively, DHA at either 10 or $25 \mu \mathrm{M}$ was added in the presence of $\mathrm{H}_{2} \mathrm{O}_{2}$. The sudden and dramatic increase in $\mathrm{APD}_{90}$ in Figure 1A indicates the incidence of EADs. As shown in Figures 1A,B, EADs were consistently induced by $\mathrm{H}_{2} \mathrm{O}_{2}$ at 5 min after perfusion. DHA $(25 \mu \mathrm{M})$ shortened the APD 
prolongation from $894 \pm 78 \mathrm{~ms}$ to $278 \pm 52 \mathrm{~ms}$, and significantly suppressed the frequency of EADs induced by $\mathrm{H}_{2} \mathrm{O}_{2}$. The incidence of EADs was assessed by counting the number of EADs within 10 APs (from eight cells) in control, after $\mathrm{H}_{2} \mathrm{O}_{2}(200 \mu \mathrm{M})$ and $\mathrm{H}_{2} \mathrm{O}_{2}(200 \mu \mathrm{M})+$ DHA (at 10 or $25 \mu \mathrm{M}$ ). The incidence of EAD was suppressed in all tested cells $(n=8)$, five of which showed complete abolishment of EADs after 3-5 min of treatment with $25 \mu \mathrm{M}$ DHA. As summarized in Figure 1C, the incidence of $\mathrm{H}_{2} \mathrm{O}_{2}$-induced EADs were significantly reduced by direct perfusion of DHA at both 10 and $25 \mu \mathrm{M}$, in a dose-dependent manner ( $p<0.05$ and $p<0.01$, respectively, Fisher's exact test).

\section{INHIBITORY EFFECT OF DHA ON ICAL ENHANCED BY $\mathrm{H}_{2} \mathrm{O}_{2}$}

Our previous studies have shown that reactivation of $I_{\text {Ca.L }}$ plays a key role in $\mathrm{H}_{2} \mathrm{O}_{2}$-induced $\mathrm{EAD}$ in rabbit ventricular myocytes (Xie et al., 2009; Song et al., 2010). Therefore, we first assessed the potential involvement of $I_{\text {Ca.L }}$ in the inhibitory effect of DHA on $\mathrm{H}_{2} \mathrm{O}_{2}$-induced EADs. $I_{\text {Ca.L }}$ was recorded in rabbit ventricular myocytes using the perforated whole-cell patch-clamp technique under voltage-clamp mode. As shown in Figure $2 \mathrm{~A}, \mathrm{H}_{2} \mathrm{O}_{2}$ $(200 \mu \mathrm{M})$ gradually increased the amplitude of $I_{\mathrm{Ca} . \mathrm{L}}$ at both peak and late phases (at $\sim 250 \mathrm{~ms}$ ), which reached the steady state at 5-7 $\mathrm{min}$, consistent with the time course for EAD induction as shown in Figure 1. The I-V relations for the peak current (Figure 2B) showed that the $I_{\mathrm{Ca} . \mathrm{L}}$ amplitude was pronouncedly increased at testing potentials -10 to $+40 \mathrm{mV}$. For example a $46.4 \%$ enhancement was caused at $0 \mathrm{mV}$, i.e., from $-8.4 \pm 1.4$ to
$-12.3 \pm 1.8 \mathrm{pA} / \mathrm{pF}(n=6, p<0.01)$. DHA $(25 \mu \mathrm{M})$ significantly suppressed/reversed the elevation of the $I_{\mathrm{Ca}, \mathrm{L}}$ amplitude (e.g., to $-7.1 \pm 0.9 \mathrm{pA} / \mathrm{pF}$ at $0 \mathrm{mV} ; n=6, p<0.01$ compared to $\mathrm{H}_{2} \mathrm{O}_{2-}$ induced effect). In order to test the DHA effect on $I_{\text {Ca.L }}$ under normal membrane potential conditions, we also performed APclamp experiments. As shown in Figures 2C,D, DHA markedly decreased both the peak and the late phase of $I_{\text {Ca.L, }}$ which were enhanced by $\mathrm{H}_{2} \mathrm{O}_{2}$, under AP-clamp conditions.

\section{INHIBITORY EFFECT OF DHA ON LATE SODIUM CURRENT INCREASED BY $\mathrm{H}_{2} \mathbf{O}_{2}$}

Since the activation of late $I_{\mathrm{Na}}$ also contributes to EAD generation induced by $\mathrm{H}_{2} \mathrm{O}_{2}$ (Ward and Giles, 1997; Xie et al., 2009), we next evaluated the effect of DHA on $\mathrm{H}_{2} \mathrm{O}_{2}$-enhanced late $I_{\mathrm{Na}}$. Late $I_{\mathrm{Na}}$ was elicited by $300 \mathrm{~ms}$ voltage-clamp pulses from -90 to $-30 \mathrm{mV}$ at a PCL of $6 \mathrm{~s}$. The magnitude of late $I_{\mathrm{Na}}$ was evaluated by integration of the area $(\mathrm{nA} \times \mathrm{ms}=\mathrm{pC})$ of the current over the last $50 \mathrm{~ms}$ of the $-30 \mathrm{mV}$ depolarizing pulse, using the integration (area) feature of the pCLAMP program. As shown in Figure 3, the late current component was significantly enhanced by $\mathrm{H}_{2} \mathrm{O}_{2}(200 \mu \mathrm{M})$ from $-0.7 \pm 0.1 \mathrm{pC}$ to $-3.2 \pm 0.3 \mathrm{pC}(n=5$, $p<0.01)$ at $4-6 \mathrm{~min}$ after perfusion, when it reaches steady state level. This elevation was completely suppressed by Tetrodotoxin (TTX, $10 \mu \mathrm{M}$ ), a selective $I_{\mathrm{Na}}$ inhibitor, confirming this late sustained inward current is due to late $I_{\mathrm{Na}}$, although we cannot exclude minor contaminations on the baseline current from other currents such as Na-Ca exchange current $\left(I_{\mathrm{NCX}}\right), I_{\mathrm{Ca}, \mathrm{L}}$ or leaky

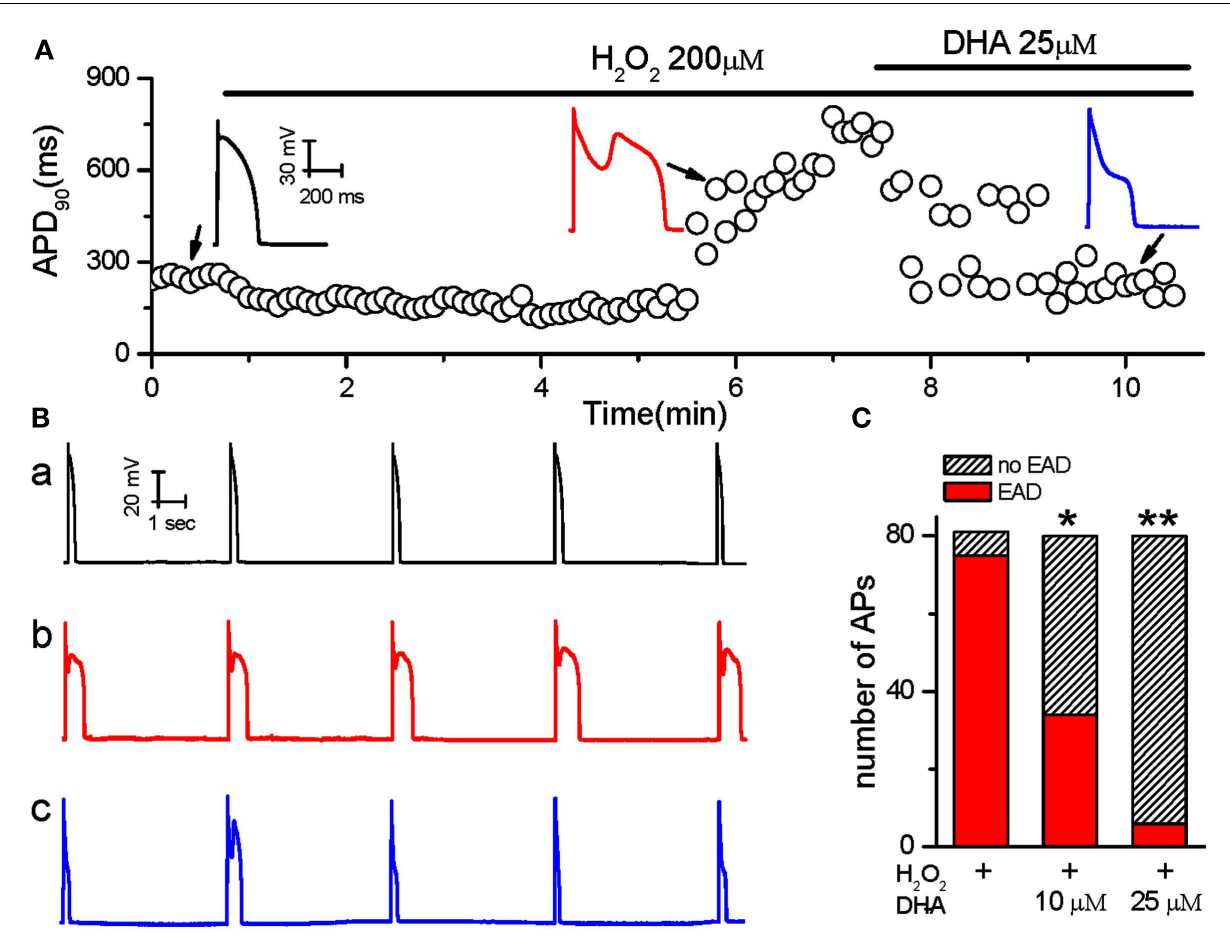

FIGURE 1 |The inhibitory effects of DHA on Early afterdepolarizations (EADs) induced by $\mathrm{H}_{2} \mathrm{O}_{2}$. (A) Values of consecutive $A P D_{90}$ are plotted over time. The ventricular myocyte was treated with $\mathrm{H}_{2} \mathrm{O}_{2}$ and DHA as indicated by the horizontal bars above the plot. Three representative AP recordings under different conditions are shown in the insets. (B) Five consecutive AP recordings from a cell exposed to control perfusate (a), $200 \mu \mathrm{M} \mathrm{H}_{2} \mathrm{O}_{2}$ (b) and $200 \mu \mathrm{M} \mathrm{H}_{2} \mathrm{O}_{2}+25 \mu \mathrm{M} \mathrm{DHA}$ (c). (C) Summarized bar graph showing dose-dependent inhibitory effects of DHA on the incidence of EADs induced by $\mathrm{H}_{2} \mathrm{O}_{2}$ ( $n=8$ cells). ${ }^{*} p<0.05,{ }^{*} p<0.01$; Fisher's Exact Test vs. $\mathrm{H}_{2} \mathrm{O}_{2}$. 


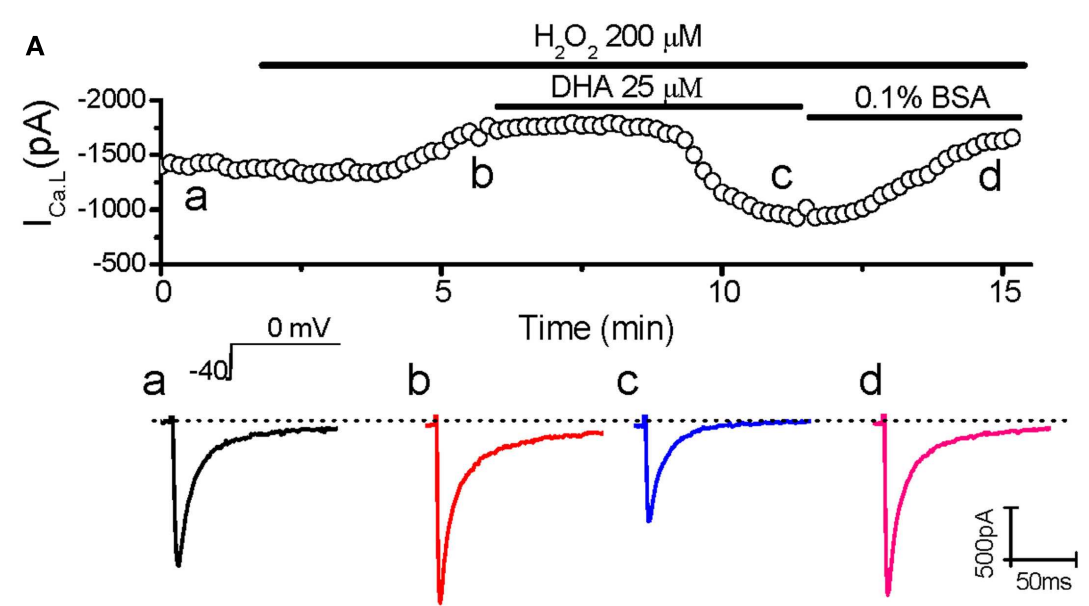

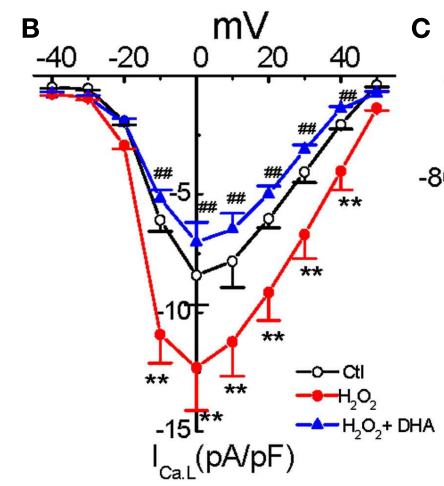

C

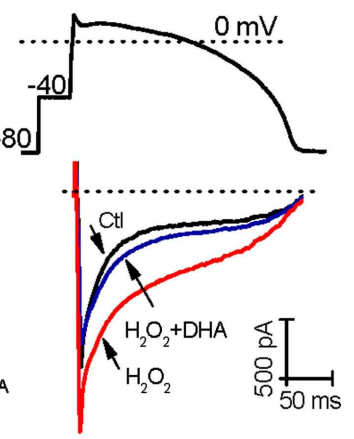

D

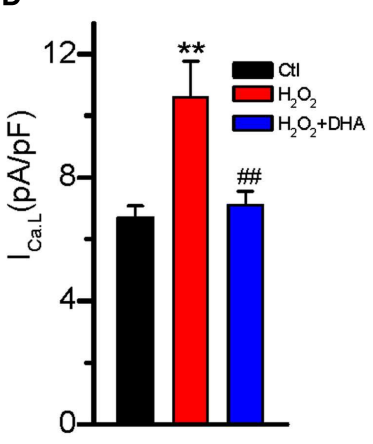

FIGURE 2 | Inhibitory effects of DHA on $I_{\text {Ca.L }}$ enhanced by $\mathrm{H}_{\mathbf{2}} \mathrm{O}_{\mathbf{2}}$. (A) Time course of peak $I_{\mathrm{Ca}, \mathrm{L}}$ in a myocyte treated with $200 \mu \mathrm{M} \mathrm{H}_{2} \mathrm{O}_{2}$ in the absence and presence of $25 \mu \mathrm{M} \mathrm{DHA}$, and $0.1 \%$ bovine serum albumin (BSA). Representative traces of $I_{\mathrm{Ca}, \mathrm{L}}$ corresponding to points a-d are shown under the plot. (B) The current-voltage relations for peak $I_{\mathrm{Ca}, \mathrm{L}}$ from six cells treated with $200 \mu \mathrm{M} \mathrm{H}_{2} \mathrm{O}_{2}$ in the absence and presence of $25 \mu \mathrm{M} \mathrm{DHA}$. Test potentials ranged from -40 to $+50 \mathrm{mV}$ in $10 \mathrm{mV}$ steps. (C) An AP-clamp waveform (above) and superimposed current traces showing $I_{\mathrm{Ca}, \mathrm{L}}$ under control (Ctl), in the presence of $200 \mu \mathrm{M}$ $\mathrm{H}_{2} \mathrm{O}_{2}$, and $\mathrm{DHA}(25 \mu \mathrm{M})+\mathrm{H}_{2} \mathrm{O}_{2}$ are shown respectively. (D) The late phase currents measured at 30-150 ms after the upstroke in (C) were summarized showing an inhibitory effect of DHA on the enhancement of $I_{\mathrm{Ca}, \mathrm{L}}$ by $\mathrm{H}_{2} \mathrm{O}_{2}(n=6)$. ${ }^{*} p<0.01$ vs. control; $\# \# p<0.01$ vs. $\mathrm{H}_{2} \mathrm{O}_{2}$ group. current. $\mathrm{H}_{2} \mathrm{O}_{2}$-increased late $I_{\mathrm{Na}}$ was effectively attenuated by $25 \mu \mathrm{M}$ DHA (to $-0.8 \pm 0.2 \mathrm{pC}$ at $2-4 \mathrm{~min}$ after DHA application, $n=5, p<0.01)$.

\section{EFFECT OF DHA ON $I_{\text {TO }}$ INCREASED BY $\mathrm{H}_{\mathbf{2}} \mathbf{O}_{\mathbf{2}}$}

Consistent with our recent finding (Zhao et al., 2012b), $\mathrm{H}_{2} \mathrm{O}_{2}$ $(200 \mu \mathrm{M}$ ) increased the amplitudes of both peak (from $8.94 \pm 1.07$ to $12.8 \pm 1.21 \mathrm{pA} / \mathrm{pF}$ at testing potential of $50 \mathrm{mV}, n=6, p<0.01$ ) and steady state (late phase at the end of $400 \mathrm{~ms}$ pulse; from $2.16 \pm 0.25$ to $3.13 \pm 0.47 \mathrm{pA} / \mathrm{pF}, n=6, p<0.01)$ component of $I_{\text {to }}$. Additionally, $\mathrm{H}_{2} \mathrm{O}_{2}$ also slowed inactivation

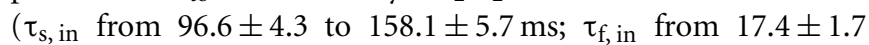
to $24.7 \pm 14.0 \mathrm{~ms}, n=7, p<0.01)$. However, DHA at $25 \mu \mathrm{M}$, the concentration which dramatically suppressed $\mathrm{H}_{2} \mathrm{O}_{2}$-induced EADs, did not show any significant effects on current amplitudes (peak $I_{\text {to }}=12.51 \pm 1.47 \mathrm{pA} / \mathrm{pF} ; I_{\text {to.ss }}=3.34 \pm 0.31 \mathrm{pA} / \mathrm{pF}, n=6$, $p>0.05$ compared to $\mathrm{H}_{2} \mathrm{O}_{2}$, respectively) or inactivation process of $I_{\text {to }}\left(\tau_{\mathrm{s}, \text { in }}: 154.6 \pm 6.6 \mathrm{~ms}\right.$ and $\tau_{\mathrm{f}, \text { in }}: 23.9 \pm 1.1 \mathrm{~ms}, n=7, p>0.05$ compared to $\mathrm{H}_{2} \mathrm{O}_{2}$; Figures $4 \mathrm{~A}-\mathrm{C}$ ). Furthermore, we found that $\mathrm{H}_{2} \mathrm{O}_{2}$ accelerated the recovery from inactivation of $I_{\text {to }}$ mainly by decreasing the fast component $\left(\tau_{\mathrm{f} . \mathrm{re}}\right.$ : from $817.2 \pm 79.2 \mathrm{~ms}$ to $341.9 \pm 26.1 \mathrm{~ms}, n=7, p<0.05)$, but not by changing the slow component ( $\tau_{\text {s.re }}$ : from control $5335.4 \pm 504.8 \mathrm{~ms}$ to $\mathrm{H}_{2} \mathrm{O}_{2}$ $4963.2 \pm 459.9 \mathrm{~ms}, p>0.05)$. Similarly DHA $(25 \mu \mathrm{M})$ did not cause any significant alteration in $I_{\text {to }}$ recovery kinetics after $\mathrm{H}_{2} \mathrm{O}_{2}$ treatment (Figure 4D).

\section{EFFECT OF DHA ON INTRACELLULAR ROS LEVELS}

The level of oxidative stress may either increase or decrease in tissues from humans and animals supplemented with fish oil as reported previously (Garrido et al., 1989; Mas et al., 2010; Tsuduki et al., 2011). To determine whether DHA reduces the incidence of EAD via affecting (decreasing) intracellular ROS, the effect of DHA on intracellular ROS levels was measured in isolated ventricular myocytes treated with exogenous $\mathrm{H}_{2} \mathrm{O}_{2}(200 \mu \mathrm{M})$ by monitoring CM-DCF fluorescence intensity. The effect of DHA on intracellular ROS levels in the absence of $\mathrm{H}_{2} \mathrm{O}_{2}$ was also measured. As shown in Figure 5, exogenous $\mathrm{H}_{2} \mathrm{O}_{2}$ produced a rapid and dramatic increase in DCF fluorescence intensity in the myocytes and the $\mathrm{F} / \mathrm{F}_{0}$ of DCF fluorescence intensity reached a steady state value of $2.18 \pm 0.24$ at $6-10 \mathrm{~min}$ after $\mathrm{H}_{2} \mathrm{O}_{2}$ treatment. However, DHA $(25 \mu \mathrm{M}$, either pretreatment or after treatment) showed no 

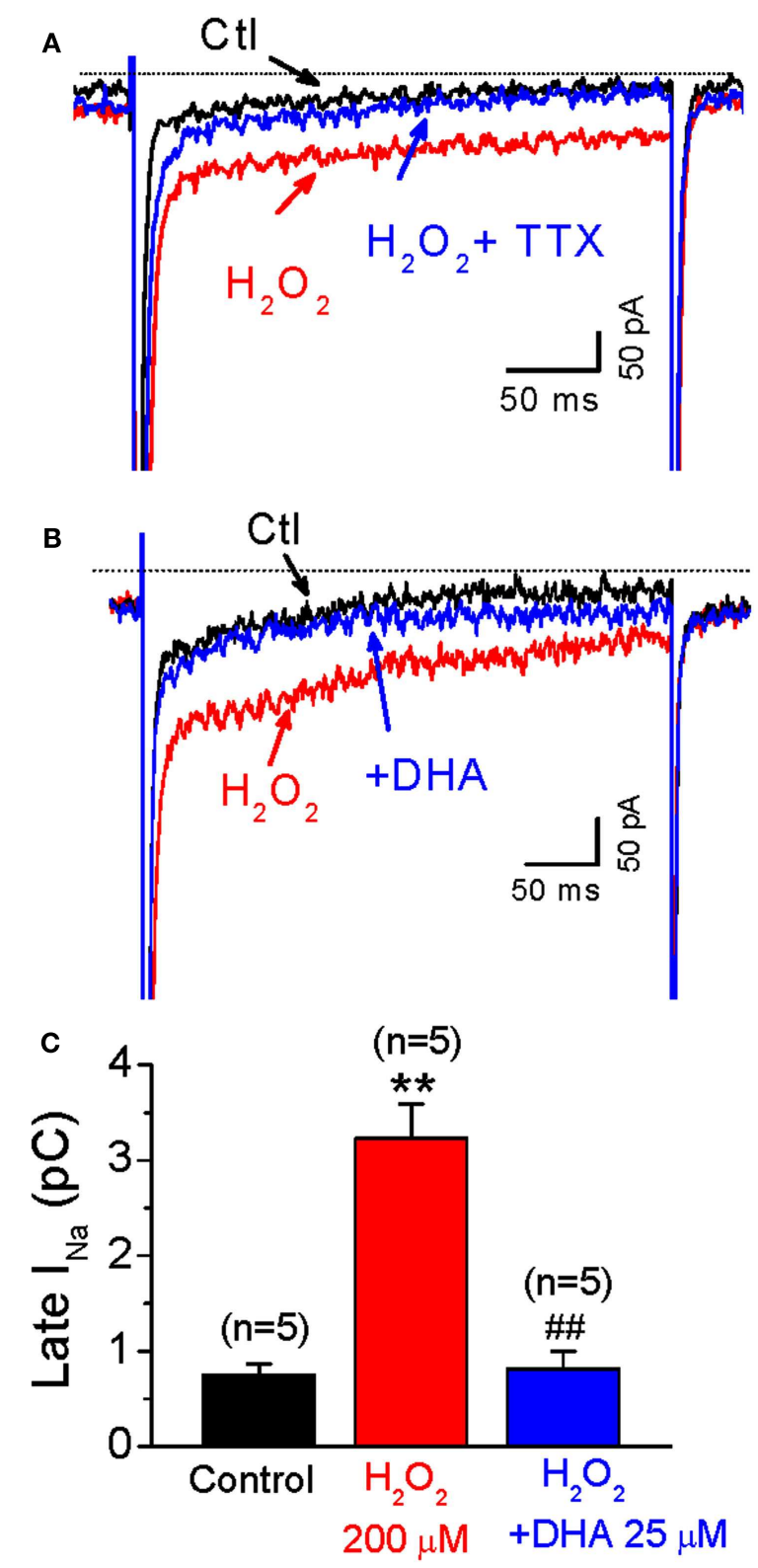

FIGURE 3 | Inhibitory effects of DHA on late $\boldsymbol{I}_{\mathrm{Na}}$ enhanced by $\mathrm{H}_{\mathbf{2}} \mathrm{O}_{\mathbf{2}}$. (A) Representative $I_{\mathrm{Na}}$ traces under control condition $(\mathrm{Ctl})$, in the presence of $200 \mu \mathrm{M} \mathrm{H} \mathrm{O}_{2}$, and $\mathrm{H}_{2} \mathrm{O}_{2}+\mathrm{TTX}(10 \mu \mathrm{M})$, respectively. (B) Representative $I_{\mathrm{Na}}$ traces under control condition (CtI), in the presence of $200 \mu \mathrm{M} \mathrm{H} \mathrm{H}_{2} \mathrm{O}$, and $\mathrm{H}_{2} \mathrm{O}_{2}+\mathrm{DHA}(25 \mu \mathrm{M})$, respectively. (C) A bar graph summarizing $200 \mu \mathrm{M}$ $\mathrm{H}_{2} \mathrm{O}_{2}$-induced increase of late $I_{\mathrm{Na}}$, which is significantly suppressed by $25 \mu \mathrm{M} \mathrm{DHA} .{ }^{* *} p<0.01$ vs. control; \#\# $p<0.01$ vs. $\mathrm{H}_{2} \mathrm{O}_{2}$ group.

significant effect on the fluorescence of CM-DCF either in the absence or presence of $\mathrm{H}_{2} \mathrm{O}_{2}(2.21 \pm 0.33, n=8, p>0.05)$.

\section{DISCUSSION}

Experimental and clinical studies have obtained controversial results regarding the effects of fish oil or $\omega-3$ PUFA on cardiac rhythm (von Schacky, 2008). Differences in the underlying pathogenic mechanisms for the arrhythmia in differing patient groups or animal models may account for these controversies. We and others have previously shown that both exogenous and endogenous ROS-induced EADs can serve as triggers for arrhythmias. In the present study, we provide the first evidence showing that DHA attenuates EADs induced by $\mathrm{H}_{2} \mathrm{O}_{2}$.

The molecular and ionic mechanisms of ion channel modulation by DHA are still not completely understood. A recent review article comprehensively summarized the potential antiarrhythmogenic electrophysiological effect of $\omega 3$-PUFAs on the heart (Richardson et al., 2011). Inhibitory effects of DHA on EADs may involve multifactorial mechanisms e.g., (1) via ROS modulation. Although $\omega 3$-PUFA may slightly increase levels of oxidative stress due to the susceptibility to oxidation, low to moderate ROS exposure can conversely give rise to up-regulation of antioxidant enzymes and increase antioxidant ability (scavenging ROS) in cardiac tissue (Jahangiri et al., 2006); (2) via direct modulation of ion channels by binding to the channels or affecting cell membrane lipid properties (such as membrane lipid peroxidation). While there is a widespread effect of $\omega 3$-PUFA on ion channels and ion pumps, $\mathrm{Ca}^{2+}$ and $\mathrm{Na}^{+}$currents are most sensitive to $\omega 3$-PUFAs (Richardson et al., 2011). Nevertheless, our present data suggest that the ionic mechanisms underlying inhibitory effect of DHA on EADs most likely involve the direct inhibition on the $I_{\mathrm{Ca}, \mathrm{L}}$ and late $I_{\mathrm{Na}}$ rather than its putative antioxidant ability. This notion was supported by the observation that there was no effect on CM-DCF fluorescence induced by DHA at the same concentration that led to reduction of EADs. In addition, the fast time course for DHA suppression of $I_{\mathrm{Ca}, \mathrm{L}}$ and late $I_{\mathrm{Na}}$ also supports a mechanism of direct inhibition of ion channels by DHA. Our most recent data showed $\mathrm{H}_{2} \mathrm{O}_{2}$ also activates $I_{\text {to }}$ and may facilitate EAD generation (Zhao et al., 2012b). In the present study, however, we showed that DHA did not reverse the $I_{\text {to }}$ activated by $\mathrm{H}_{2} \mathrm{O}_{2}$ in rabbit ventricular myocytes, which is inconsistent with previous reports that DHA markedly reduces $I_{\text {to }}$ in human atrial cells and rat ventricular myocytes even at lower concentrations (5-10 $\mu \mathrm{M}$; Bogdanov et al., 1998; Verkerk et al., 2006; Li et al., 2009). We do not have a ready explanation for this discrepancy, while the molecular subtypes of $I_{\text {to }}$ proteins might be different between rabbits and other species (including humans) or between different locations in the heart (e.g., ventricle vs. atria). In addition, the $\mathrm{H}_{2} \mathrm{O}_{2}$-activated $I_{\text {to }}$ seemed to be more resistant to DHA than the $I_{\text {to }}$ at baseline, since we observed the inhibitory effects of $25 \mu \mathrm{M}$ DHA on $I_{\text {to }}$ (up to $\sim 50 \%$ ) in the absence of $\mathrm{H}_{2} \mathrm{O}_{2}$.

It has also been reported that $\mathrm{n}-3$-PUFAs are capable of reducing the activity of CaMKII (Zaloga et al., 2006), which may partially account for the inhibitory effect of DHA on EADs. However, since DHA does not alter the ROS level in the presence of $\mathrm{H}_{2} \mathrm{O}_{2}$ (Figure 5), the reduction of CaMKII activity, if any, may be mediated by less $\mathrm{Ca}$ entry secondarily to $I_{\mathrm{Ca}, \mathrm{L}}$ blockage, rather than by lower oxidation. Further experiments are needed identify the involvement of CaMKII.

Nevertheless, our present study suggests fish oil supplements may be effective in preventing/treating arrhythmias under an increased oxidative stress condition and serve as an alternative or complimentary anti-arrhythmic drug. Conditions with elevated oxidative stress level including ischemia/reperfusion, heart failure and aging might benefit from fish oil supplements. 

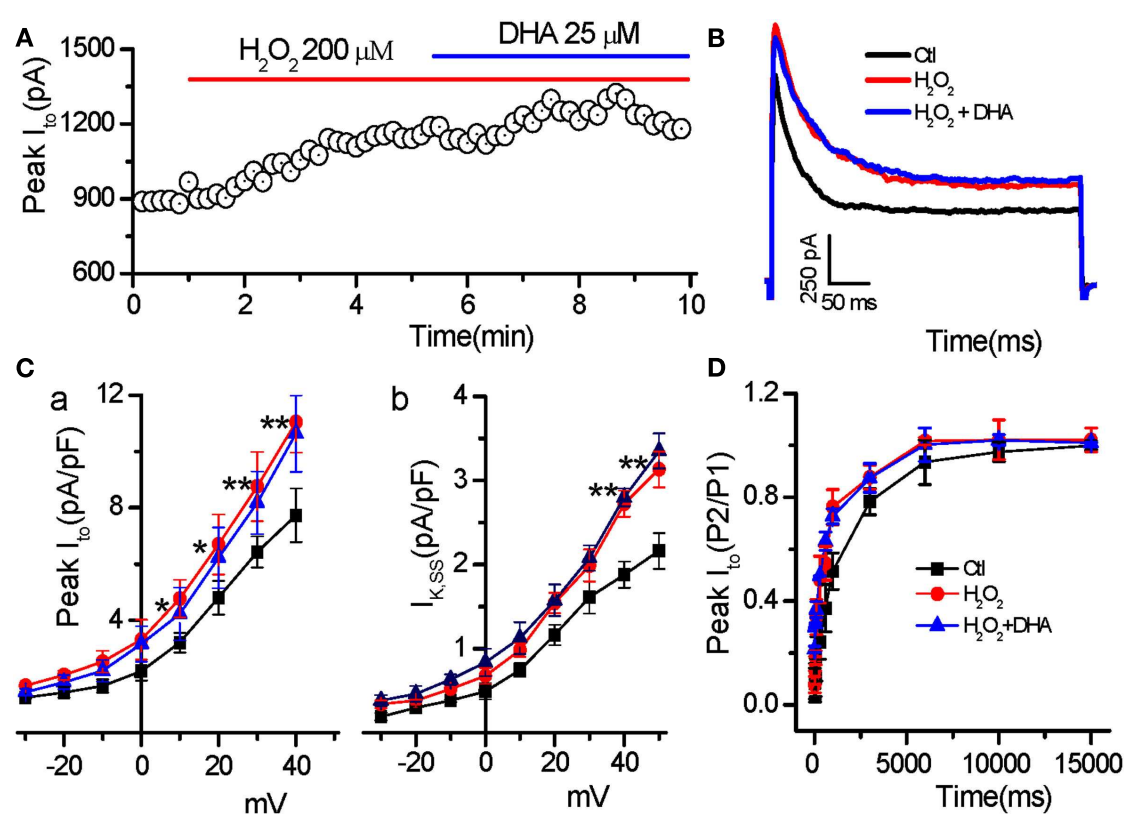

FIGURE 4 | Less effect of DHA on $\boldsymbol{I}_{\text {to }}$ enhanced by $\mathrm{H}_{\mathbf{2}} \mathbf{O}_{\mathbf{2}}$. (A) Time course of peak $I_{\text {to }}$ in a myocyte treated with $\mathrm{H}_{2} \mathrm{O}_{2}$ in the absence and presence of DHA. (B) Representative traces of the $I_{\text {to }}$ under control, in the presence of $\mathrm{H}_{2} \mathrm{O}_{2}(200 \mu \mathrm{M})$, and $\mathrm{H}_{2} \mathrm{O}_{2}+\mathrm{DHA}(25 \mu \mathrm{M})$, respectively. (C) Current-voltage relations of the peak $I_{\text {to }}$ (C-a) and steady state currents
$\left(I_{\mathrm{K}, \mathrm{SS}}, \mathbf{C}-\mathbf{b}\right)$ showing less effects of DHA on enhancement of peak $I_{\text {to }}$ and $I_{\text {K.ss }}\left(n=6,{ }^{*} p<0.05,{ }^{*} p<0.01\right.$ vs. control.). Test potentials ranged from -60 to $+50 \mathrm{mV}$ in $10 \mathrm{mV}$ steps. (D) Recovery of $I_{\text {to }}$ from inactivation showing no significant effect of DHA $(25 \mu \mathrm{M})$ on the $I_{\text {to }}$ recovery sped-up by $\mathrm{H}_{2} \mathrm{O}_{2}(200 \mu \mathrm{M} ; p>0.05, n=7)$.
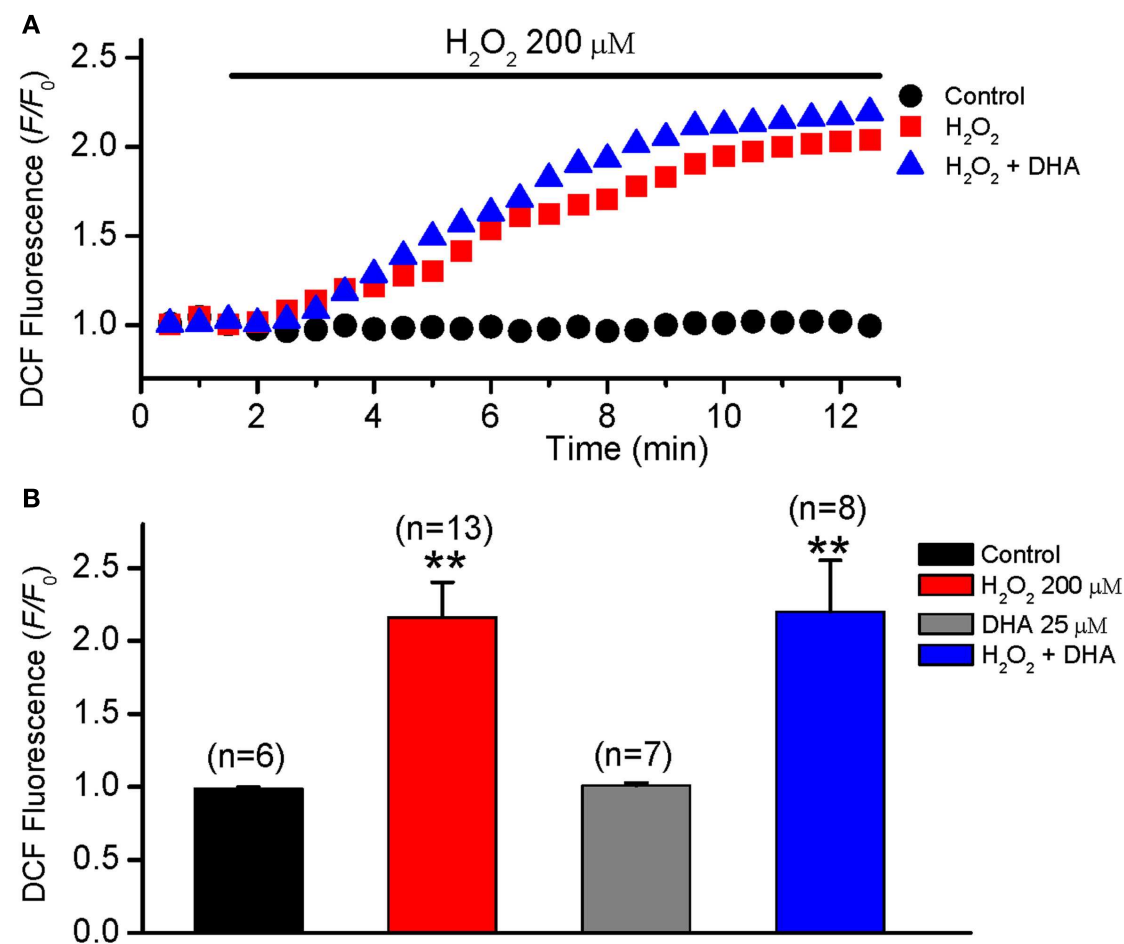

FIGURE 5 | No effect of DHA on ROS levels in isolated rabbit ventricular myocytes. ROS levels were measured by monitoring DCF fluorescence intensity in isolated myocytes every $30 \mathrm{~s}$ in control, $\mathrm{H}_{2} \mathrm{O}_{2}(200 \mu \mathrm{M})$ and $\mathrm{H}_{2} \mathrm{O}_{2}+\mathrm{DHA}(25 \mu \mathrm{M})$ groups. (A) Time courses of DCF fluorescence intensity
$\left(F / F_{0}\right)$ in three representative myocytes from the three groups, respectively. (B) Histograms summarizing the DCF intensities for each group measured at 6 min after treatment of $\mathrm{H}_{2} \mathrm{O}_{2} .{ }^{*} p<0.01$ compared to control. Numbers in parentheses indicate the number of cells in each group. 


\section{ACKNOWLEDGMENTS}

This work was supported by National Natural Science Foundation of China No. 30930105 (to Weijin Zang) and No. 81170597 (to Zhenghang Zhao), Major International

\section{REFERENCES}

Berecki, G., Den Ruijter, H. M., Verkerk, A. O., Schumacher, C. A., Baartscheer, A., Bakker, D., Boukens, B. J., Van Ginneken, A. C., Fiolet, J. W., Opthof, T., and Coronel, R. (2007). Dietary fish oil reduces the incidence of triggered arrhythmias in pig ventricular myocytes. Heart Rhythm 4, 1452-1460.

Bogdanov, K. Y., Spurgeon, H. A., Vinogradova, T. M., and Lakatta, E. G. (1998). Modulation of the transient outward current in adult rat ventricular myocytes by polyunsaturated fatty acids. Am. J. Physiol. 274, H571-H579.

Cheng, J. W., and Santoni, F. (2008). Omega-3 fatty acid: a role in the management of cardiac arrhythmias? J. Altern. Complement. Med. 14, 965-974.

Coronel, R., Wilms-Schopman, F. J., Den Ruijter, H. M., Belterman, C. N., Schumacher, C. A., Opthof, T., Hovenier, R., Lemmens, A. G., Terpstra, A. H., Katan, M. B., and Zock, P. (2007). Dietary n-3 fatty acids promote arrhythmias during acute regional myocardial ischemia in isolated pig hearts. Cardiovasc. Res. 73, 386-394.

Den Ruijter, H. M., Berecki, G., Opthof, T., Verkerk, A. O., Zock, P. L., and Coronel, R. (2007). Pro- and antiarrhythmic properties of a diet rich in fish oil. Cardiovasc. Res. 73, 316-325.

Den Ruijter, H. M., Berecki, G., Verkerk, A. O., Bakker, D., Baartscheer, A., Schumacher, C. A., Belterman, C. N., De Jonge, N., Fiolet, J. W., Brouwer, I. A., and Coronel, R. (2008). Acute administration of fish oil inhibits triggered activity in isolated myocytes from rabbits and patients with heart failure. Circulation 117, 536-544.

Den Ruijter, H. M., Verkerk, A. O., Berecki, G., Bakker, D., Van Ginneken, A. C., and Coronel, R. (2006). Dietary fish oil reduces the occurrence of early afterdepolarizations in pig ventricular myocytes. J. Mol. Cell. Cardiol. 41, 914-917.

Garrido, A., Garrido, F., Guerra, R., and Valenzuela, A. (1989). Ingestion of high doses of fish oil increases the susceptibility of cellular membranes to the induction of oxidative stress. Lipids 24, 833-835.

Jahangiri, A., Leifert, W. R., Kind, K. L., and McMurchie, E. J. (2006). Dietary fish oil alters cardiomyocyte $\mathrm{Ca}^{+}$ dynamics and antioxidant status. Free Radic. Biol. Med. 40, 1592-1602.

Li, G. R., Sun, H. Y., Zhang, X. H., Cheng, L. C., Chiu, S. W., Tse, H. F., and Lau, C. P. (2009). Omega-3 polyunsaturated fatty acids inhibit transient outward and ultra-rapid delayed rectifier $\mathrm{K}^{+}$currents and $\mathrm{Na}^{+}$current in human atrial myocytes. Cardiovasc. Res. 81, 286-293.

London, B., Albert, C., Anderson, M. E., Giles, W. R., Van Wagoner, D. R., Balk, E., Billman, G. E., Chung, M., Lands, W., Leaf, A., McAnulty, J., Martens, J. R., Costello, R. B., and Lathrop, D. A. (2007). Omega-3 fatty acids and cardiac arrhythmias: prior studies and recommendations for future research: a report from the National Heart, Lung, and Blood Institute and Office Of Dietary Supplements Omega-3 Fatty Acids and their Role in Cardiac Arrhythmogenesis Workshop. Circulation 116, e320-e335.

Mas, E., Woodman, R. J., Burke, V., Puddey, I. B., Beilin, L. J., Durand, T., and Mori, T. A. (2010). The omega-3 fatty acids EPA and DHA decrease plasma $F(2)$-isoprostanes: results from two placebo-controlled interventions. Free Radic. Res. 44, 983-990.

Nodari, S., Metra, M., Milesi, G., Manerba, A., Cesana, B. M., Gheorghiade, M., and Dei Cas, L. (2009). The role of n-3 PUFAs in preventing the arrhythmic risk in patients with idiopathic dilated cardiomyopathy. Cardiovasc. Drugs Ther. 23, 5-15.

Rae, J., Cooper, K., Gates, P., and Watsky, M. (1991). Low access resistance perforated patch recordings using amphotericin B. J. Neurosci. Methods 37, 15-26.

Raitt, M. H., Connor, W. E., Morris, C., Kron, J., Halperin, B., Chugh, S. S., McClelland, J., Cook, J., MacMurdy, K., Swenson, R., Connor, S. L., Gerhard, G., Kraemer, D. F., Oseran, D., Marchant, C., Calhoun, D., Shnider, R., and McAnulty, J. (2005). Fish ventricular tachycardia and ventricular fibrillation in patients with implantable defibrillators: a randomized controlled trial. JAMA 293, 2884-2891.

Richardson, E. S., Iaizzo, P. A., and Xiao, Y. F. (2011). Electrophysiological mechanisms of the anti-arrhythmic oil supplementation and risk of

(Regional) Joint Research Project of National Natural Science Foundation of China No. 81120108002 (to Weijin Zang), and NIH/NHLBI R01 HL97979 (to Lai-Hua Xie).

effects of omega-3 fatty acids. $J$. Cardiovasc. Transl. Res. 4, 42-52.

Sato, D., Xie, L. H., Sovari, A. A., Tran, D. X., Morita, N., Xie, F., Karagueuzian, H., Garfinkel, A., Weiss, J. N., and Qu, Z. (2009). Synchronization of chaotic early afterdepolarizations in the genesis of cardiac arrhythmias. Proc. Natl. Acad. Sci. U.S.A. 106, 2983-2988.

Smith, P. J., Blumenthal, J. A., Babyak, M. A., Georgiades, A., Sherwood, A., Sketch, M. H. Jr., and Watkins, L. L. (2009). Association between n-3 fatty acid consumption and ventricular ectopy after myocardial infarction. Am. J. Clin. Nutr. 89, 1315-1320.

Song, Y., Shryock, J. C., Wagner, S. Maier, L. S., and Belardinelli, L. (2006). Blocking late sodium current reduces hydrogen peroxide-induced arrhythmogenic activity and contractile dysfunction. J. Pharmacol. Exp. Ther. 318, 214-222.

Song, Y. H., Cho, H., Ryu, S. Y. Yoon, J. Y., Park, S. H., Noh, C. I., Lee, S. H., and Ho, W. K. (2010). L-type $\mathrm{Ca}^{+}$channel facilitation mediated by $\mathrm{H} 2 \mathrm{O} 2$-induced activation of CaMKII in rat ventricular myocytes. J. Mol. Cell. Cardiol. 48, 773-780.

Tsuduki, T., Honma, T., Nakagawa, K. Ikeda, I., and Miyazawa, T. (2011). Long-term intake of fish oil increases oxidative stress and decreases lifespan in senescence-accelerated mice. Nutrition 27, 334-337.

Verkerk, A. O., Van Ginneken, A. C., Berecki, G., Den Ruijter, H. M., Schumacher, C. A., Veldkamp, M. W., Baartscheer, A., Casini, S. Opthof, T., Hovenier, R., Fiolet, J. W., Zock, P. L., and Coronel, R. (2006). Incorporated sarcolemmal fish oil fatty acids shorten pig ventricular action potentials. Cardiovasc. Res. 70, 509-520.

von Schacky, C. (2008). Omega-3 fatty acids: antiarrhythmic, proarrhythmic or both? Curr. Opin. Clin. Nutr. Metab. Care 11, 94-99.

Ward, C. A., and Giles, W. R. (1997) Ionic mechanism of the effects of hydrogen peroxide in rat ventricular myocytes. J. Physiol. (Lond.) 500(Pt 3), 631-642.

Xie, L. H., Chen, F., Karagueuzian, H. S. and Weiss, J. N. (2009). Oxidativestress-induced afterdepolarizations and calmodulin kinase II signaling. Circ. Res. 104, 79-86.
Zaloga, G. P., Ruzmetov, N., Harvey, K. A., Terry, C., Patel, N., Stillwell, W., and Siddiqui, R. (2006). (N-3) longchain polyunsaturated fatty acids prolong survival following myocardial infarction in rats. J. Nutr. 136, 1874-1878.

Zhao, Z., Fefelova, N., Shanmugam, M., Bishara, P., Babu, G. J., and Xie, L. H. (2011). Angiotensin II induces afterdepolarizations via reactive oxygen species and calmodulin kinase II signaling. J. Mol. Cell. Cardiol. 50, 128-136.

Zhao, Z., Wen, H., Fefelova, N., Allen, C., Baba, A., Matsuda, T., and Xie, L. H. (2012a). Revisiting the ionic mechanisms of early afterdepolarizations in cardiomyocytes: predominant by $\mathrm{Ca}$ waves or Ca currents? Am. J. Physiol. Heart Circ. Physiol. 302, C1762-C1771.

Zhao, Z., Xie, Y., Wen, H., Xiao, D., Allen, C., Fefelova, N., Dun, W., Boyden, P., Qu, Z., and Xie, L. H. (2012b). Role of the transient outward potassium current in the genesis of early afterdepolarizations in cardiac cells. Cardiovasc. Res. PMID: 22660482. [Epub 2012 June 1].

Conflict of Interest Statement: The authors declare that the research was conducted in the absence of any commercial or financial relationships that could be construed as a potential conflict of interest.

Received: 01 May 2012; paper pending published: 15 May 2012; accepted: 18 June 2012; published online: 09 July 2012. Citation: Zhao Z, Wen H, Fefelova $N$, Allen C, Guillaume N, Xiao D, Huang $C$, Zang W, Gwathmey JK and Xie L$H$ (2012) Docosahexaenoic acid reduces the incidence of early afterdepolarizations caused by oxidative stress in rabbit ventricular myocytes. Front. Physio. 3:252. doi: 10.3389/fphys.2012.00252

This article was submitted to Frontiers in Cardiac Electrophysiology, a specialty of Frontiers in Physiology. Copyright (C) 2012 Zhao, Wen, Fefelova, Allen, Guillaume, Xiao, Huang, Zang, Gwathmey and Xie. This is an openaccess article distributed under the terms of the Creative Commons Attribution License, which permits use, distribution and reproduction in other forums, provided the original authors and source are credited and subject to any copyright notices concerning any third-party graphics etc. 